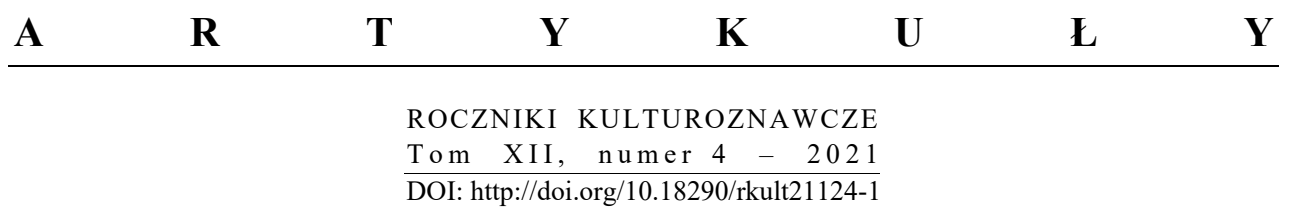

GRZEGORZ GRZYBEK

\title{
KULTUROWY WYMIAR WOLNOŚCI RELIGIJNEJ A WYCHOWANIE. WSPÓŁCZESNE ZNACZENIE DEKLARACJI O WOLNOŚCI RELIGIJNEJ
}

\section{WPROWADZENIE}

Kultura stanowi kluczowe otoczenie dla wychowania. Dokument, który ma być inspiracją dla niniejszej refleksji obrazuje także przejaw historycznych przemian kulturowych $\mathrm{w}$ zakresie społecznego funkcjonowania religii. Pytanie jakie tutaj trzeba sobie zadać, to jak może i powinien się on przekładać na wychowanie do wolności religijnej. Refleksja będzie miała trzy etapy. Pierwszy ma na celu przybliżyć samo pojmowanie religii, drugi na bazie tego przybliżenia ukazać prawo do wolności religijnej, trzeci zaś punkt ma wskazać na ważne elementy wychowania do wolności religijnej.

\section{RELIGIA JAKO FENOMEN KULTURY}

Religia jest obecna w kulturze między innymi poprzez swoje symbole, które aby były właściwie rozumiane nie mogą być dowolnie zmieniane czy też interpretowane ${ }^{1}$. O właściwą interpretację symboli religijnych oraz istoty wiary dba sama religia. Przemiany demokratyczne, których dokument Soboru

Dr hab. GRZEGORZ GRZYBEK - prof. UR, Uniwersytet Rzeszowski, Instytut Pedagogiki, Zakład Teorii Wychowania i Opieki; adres do korespondencji: Wydział Pedagogiczny, Zakład Teorii Wychowania i Opieki, ul. Ks. J. Jałowego 24, 35-010 Rzeszów; e-mail: ggwil@o2.pl; ORCID: https://orcid.org/0000-0002-8919-2429.

${ }^{1}$ Leszek KOŁAKOWSKI, „Symbole religijne i kultura humanistyczna”. W: Leszek KOŁAKOWSKI, Kultura i fetysze. Eseje (Warszawa: PWN, 2009), 223-227. 
Watykańskiego II zatytułowany Deklaracja o wolności religijnej stanowi ważny wyraz (w samym Kościele nie jest jednakowo oceniany), nie pozwalają na to, by przy pomocy władzy świeckiej narzucać interpretację religijną i domagać się uznania dla prawdziwej wiary². Wolność sądzenia i wierzenia może być odbierana $\mathrm{w}$ ten sposób, że współczesna kultura nie daje religii prawa do nieomylności. To zjawisko jest także przypisywane sekularyzacji: lęk przed sekularyzacją może wynikać z przekonania o sprzecznych przejawach kultury świeckiej i religii. Nowożytne zastrzeżenia objawiły się z całą mocą w idei Oświecenia, które rewolucja francuska umieściła na swoich sztandarach czyniąc niezależność Kościoła przeszkodą na drodze postępu. Kluczowym wymiarem postępu miał być racjonalizm i naturalizm w życiu społecznym i państwowym. Filozofia materialistyczna w sposób oczywisty dążyła do przeciwstawienia się kulturze opartej na religii uznającej Boga za rzeczywistość obiektywną. Taka filozofia nie mogła nie rodzić lęków wśród ludzi Kościoła ${ }^{3}$. Mimo różnych ocen przemian kulturowych i roli w niej religii, chyba nie należy skupiać się na publicznym wymiarze, ale zastanowić się nad wewnętrznym elementem kształtowania wolności religijnej, czyli nad wychowaniem i samowychowaniem.

Refleksja antropologiczna podkreśla, że ,wolność jest zakorzenioną w rozumie i woli możliwością działania lub niedziałania, czynienia tego lub czegoś innego, a więc podejmowania przez siebie dobrowolnych działań. Dzięki wolnej woli każdy decyduje o sobie. Wolność jest w człowieku siłą wzrastania i dojrzewania w prawdzie i dobru; osiąga ona swoją doskonałość, gdy jest ukierunkowana na Boga, który jest naszym szczęściem"4. To właśnie refleksja nad człowiekiem pozwala dostrzec w nim wymiar religijny. Można także przyjąć, iż do właściwego pojmowania człowieka niezbędne jest ukazanie jego wymiaru religijnego ${ }^{5}$.

Człowiek jako istota rozumna i wolna, świadoma swojej niewystarczalności z jednej strony, zaś z drugiej przekonana o swojej transcendencji, pyta o istotę absolutną i poszukuje Boga. Finałem tych poszukiwań jest dialog z Absolutem, źródłem religii ${ }^{6}$. Oznacza to także, iż „człowiek może nawiązać z Bogiem kontakt, który polega na otrzymaniu od tej Najmędrszej Istoty poznania

\footnotetext{
2 Józef TISCHNER, W krainie schorowanej wyobraźni (Kraków: Znak, 2013), 204-218.

${ }^{3}$ Stanisław KowalczyK, Filozofia kultury. Próba personalistycznego ujęcia problematyki (Lublin: Wydawnictwo KUL, 2005), 174.

${ }^{4}$ Katechizm Kościoła Katolickiego (Poznań: Pallottinum, 1994), 411, nr 1731.

${ }^{5}$ Roman DarowsKi, Filozofia czlowieka. Zarys problematyki. Antologia tekstów (Kraków: Ignatianum, WAM, 2008), 141.

${ }^{6}$ Ibid., 141.
} 
pewnych prawd, zarówno Pan Bóg jest bytem czysto duchowym, osobowym, rozumnym, jak z drugiej strony człowiek posiada rozum jako władzę swej duchowej duszy"7.

Czemu służy uznanie religijnego charakteru ludzkiego bytowania? „Uznanie religijnego wymiaru egzystencji ludzkiej czy jego zaprzeczenie, a zwłaszcza poznanie charakteru religijności i jej ocena zakładają nie tylko znajomość samego człowieka, nie tylko wiedzę o faktach i przeżyciach religijnych, ale przede wszystkim rozstrzygnięcie problemu realnego istnienia transcendentnego przedmiotu aktów religijnych. Od tego zależy przecież pogląd na naturę

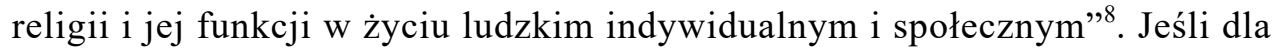
zrozumienia człowieka i tworzonej przez niego kultury ważnym jest ujęcie jego wymiaru religijnego, to zadanie wychowania do wolności religijnej wydaje się również kluczowe.

Trzeba się zatem przyjrzeć pokrótce samej religii. Religijność i religia określają człowieka jako byt rozumny i wolny oraz stanowią przeciwieństwo świata zwierząt. Przykłady religijności i religii w historii wskazują na różne formy. Fantastyczne mity oraz doświadczenie prawdy Objawionej, choć nie są do siebie przystające, to jednak podkreślają odmienność społeczności ludzkiej i środowiska zwierząt. Niezależnie od swojego pochodzenia religia stanowi szczególną formę relacji w społeczeństwie religijnie określonym. Zakazy i tabu mogą jedynie wskazać na pochodzenie religii, nie zaś zaprzeczać samej religijności człowieka. Domagają się jednak odpowiedzi na źródło pochodzenia zjawiska religii ${ }^{9}$. Człowiek, jeśli poszukuje Absolutu, to muszą być ku temu jakieś powody: „A zatem to, iż człowiek zaistniał i że jest człowiekiem, wreszcie, że może stać się sobą, stanowi «wstępne» dzieło Boga. Jest to conditio sine qua non. Pomijamy tu sprawę, jak człowiek może obcować z jakimś absolutem, który nie jest Bogiem, ale np. «naturą», «procesem historycznym», «wielkim bytem człowieczym». Na koniec obcowanie z Bogiem - zarówno wewnętrzne jak i zewnętrzne (kult i religia) - zwykliśmy nazywać religijnością, co najmniej w jej wymiarze osobistym" ${ }^{\prime 10}$. Wydaje się, że poszukiwanie Boga ma wciąż ten sam cel: zrozumienie siebie oraz siebie w świecie, który człowieka otacza.

\footnotetext{
${ }^{7}$ Karol WojtyŁA, Rozważania o istocie człowieka (Kraków: WAM, 2003), 99.

${ }^{8}$ Zofia J. ZDYBICKA, „Człowiek i religia”, w: Mieczysław A. KRĄPIEC, Ja - człowiek: zarys antropologii filozoficznej (Lublin: Wydawnictwo KUL, 2005), 357.

${ }^{9}$ Carlos Valverde, Antropologia filozoficzna, thum. Grzegorz Ostrowski (Poznań: Pallottinum, 1998), 165.

${ }^{10}$ Witold BRONIEWSKI, Szkice o człowieku. O doświadczeniu pierwotnym, obdarowaniu $i$ wielkich wyborach życiowych (Toruń: Adam Marszałek, 2006), 228-229.
} 
W doświadczeniu religijnym można wskazać na trzy elementy: 1) intuicję poznawczą; 2) poczucie uczestnictwa w uniwersalnym ładzie; 3) zobowiązanie moralne, które wynika $z$ doświadczenia religijnego ${ }^{11}$. Doświadczenie religijne oznacza także jakiś sposób wejścia jednostki w osobisty kontakt $\mathrm{z}$ bóstwem i związany z tym kontaktem specyficzny charakter realizacji oraz zaangażowania człowieka ${ }^{12}$. „Doświadczenie religijne zawiera elementy poznawcze, dążeniowe, etyczne, emocjonalne, pragmatyczne, socjologiczne itp., lecz do nich nie sprowadza się. Jest fenomenem nieredukowalnym do innych przeżyć człowieka, ma ono profil swoisty i niepowtarzalny. Swoistość życia religijnego nie oznacza jednak, aby w ludzkiej osobie istniały odrębne władze czy sfery zarezerwowane wyłącznie dla aktów religijnych. Religijność nie stanowi getta izolowanego od reszty przeżyć człowieka, ona jest natomiast aktywnością całego człowieka, jego osobowym zaangażowaniem"13.

Zwracając również uwagę na kontekst społeczny religii należy zauważyć jej znaczenie i siłę przeobrażającą ${ }^{14}$. Nie można także zapominać o tym, iż religijność podlega ciągłym zmianom. Ważny jest także związek religii z moralnością, a szczególnie w społeczeństwie polskim, wciąż religia posiada kluczowe uzasadnienie dla moralności i życiowych wyborów ${ }^{15}$.

Próbując podsumować pierwszy etap refleksji, można wskazać, że człowiek w sposób naturalny poszukuje Boga, ponieważ chce zrozumieć siebie i swoją egzystencję. Religia dostarcza nie tylko wiedzy o przedmiocie poszukiwania, ale podaje praktyczne zasady organizacji swojego życia, które wynikają ze zrozumienia przedmiotu poznania. Pozostaje zatem dookreślenie prawa do wolności takich poszukiwań i życia według rozpoznanej prawdy.

\section{PRAWO DO WOLNOŚCI RELIGIJNEJ}

Na początek warto się odwołać do sposobu określania prawa do wolności religijnej w Powszechnej Deklaracji Praw Człowieka: „Każdy człowiek ma prawo do wolności myśli, sumienia i religii. Prawo to zakłada wolność zmiany religii i przekonania, jak również wolność wyrażania własnej religii

\footnotetext{
${ }^{11}$ Jan A. KŁoczowsKI, ,Poznanie religijne. Próba charakterystyki”, Logos i Ethos 2, nr 1 (1992): 20.

12 ZDYBICKA, Człowiek i religia, 369.

${ }^{13}$ Stanisław KowalczyK, Zarys filozofii człowieka (Sandomierz: Wydawnictwo Diecezjalne, 2002), 177

${ }^{14}$ Zbigniew MAREK, Religia, pomoc czy zagrożenie dla edukacji? (Kraków: WAM, 2014), 32-33.

${ }^{15}$ Janusz MARIAŃSKI, „Religia i moralność w społeczeństwie polskim - ciągłość i zmiana”, w Wartości i więzi moralne w zmieniajacym się społeczeństwie, red. Janusz Mariański i Leon Smyczek (Kraków: WAM, 2008), 269-300.
} 
lub przekonania, indywidualnie lub zbiorowo, zarówno publicznie, jak i prywatnie, przez nauczanie, praktyki, kult i wypełnianie obrzędów"16. Prawo do wolności religijnej stanowi ważny element prawa do wolności jako takiej ${ }^{17}$. Prawo to pozwala także kwestionować samą możliwość uzyskania odpowiedzi dotyczącej istnienia Boga i pozwala bronić się przed agitacją ze strony religii, sekt oraz ich wizji zbawienia ${ }^{18}$. Uprawnienie to posiada charakter prawa osobistego ${ }^{19}$.

Papież Jan XXIII zwrócił jednak uwagę, że „do praw człowieka zalicza się również możliwość oddawania czci Bogu zgodnie z wymaganiem własnego prawego sumienia oraz wyznawania religii prywatnie i publicznie"20. Prawny aspekt religii podkreślony przez Papieża wskazuje na jednostkowe oraz społeczne uprawnienia. Należy zauważyć, że encyklika Pacem in terris jako wyraz chrześcijańskiego personalizmu stanowi przełom w zakresie przyjmowania praw człowieka w nowożytnym sformułowaniu i zaangażowania Kościoła ${ }^{21}$.

Jak sama Deklaracja określa prawo do wolności religijnej? „Sobór Watykański oświadcza, że osoba ludzka ma prawo do wolności religijnej. Wolność ta polega na tym, że wszyscy ludzie powinni być wolni od przymusu ze strony czy to jednostki, czy też grup społecznych i wszelkiej władzy ludzkiej, i to przynajmniej tak, żeby nikt nie był zmuszany do działania wbrew sumieniu ani nie doznawał przeszkody, gdy działa według swego sumienia - prywatnie czy publicznie, sam albo stowarzyszony z innymi - w należnych granicach"22. Deklaracja również podkreśla dwa aspekty wolności: osobistą i społeczną.

Należy także wskazać, że podstawą prawa do wolności religijnej jest godność osoby ludzkiej ${ }^{23}$, a człowiek obdarzony rozumem i wolną wolą może

\footnotetext{
${ }^{16}$ Powszechna Deklaracja Praw Człowieka, w: Roman DAROwski, Filozofia człowieka. Zarys problematyki. Antologia tekstów (Kraków: Ignatianum, WAM, 2008), 246, art. 18.

${ }^{17}$ Zob. Henryk SKOROwSKI, Problematyka praw człowieka (Warszawa: Wydawnictwo UKSW, 1999), 111; Grzegorz GRZYBEK, „Uprawnienie do wolności - interpretacja etyczna”, w O prawach człowieka nieco inaczej, red. Ryszard Moń i Andrzej Kobyliński (Warszawa: Wydawnictwo UKSW, 2011), 169-175.

${ }^{18}$ Ewa NowAK i Karolina CERn, Ethos w życiu publicznym (Warszawa: PWN, 2008), 247.

${ }^{19}$ Marek PIECHOWIAK, Filozofia praw czlowieka. Prawa człowieka w świetle ich międzynarodowej ochrony (Lublin: Towarzystwo Naukowe KUL, 1999), 68-71.

${ }^{20}$ JAN XXIII, Pacem in terris. Encyklika o pokoju między wszystkimi narodami opartym na prawdzie, miłości i wolności (Wrocław: TUM, 1997), 8, nr 14.

${ }^{21}$ Francesco Compagnoni, Prawa człowieka. Geneza, historia i zaangażowanie chrześcijańskie, thum. Stefan Bielański (Kraków: WAM, 2000), 201-202.

${ }^{22}$ Deklaracja o wolności religijnej Dignitatis humanae, w Sobór Watykański II. Konstytucje, dekrety, deklaracje. Tekst polski. Nowe tlumaczenie (Poznań: Pallottinum, 2002), 411, nr 2.

${ }^{23}$ Ibid.
} 
ponosić odpowiedzialność za szukanie prawdy, trwanie przy niej i kształtowanie według niej swojego życia ${ }^{24}$. Oparcie prawa do wolności religijnej na ludzkiej godności nie budzi zastrzeżeń. Natomiast samo akcentowanie wolności i jej dwa aspekty wolność jako brak przymusu (wolność „od”) oraz wolność jako obszar zadania (wolność „do”) stanowić może ważny element w refleksji nad wolnością religijną ${ }^{25}$.

Problematyczne też może być przekonanie religii o pewności swojego spojrzenia na prawdę o człowieku i Bogu ${ }^{26}$. Wydaje się, że w tym kontekście prawo do wolności religijnej także stanowi ważny wkład w zabezpieczenie jednostki ludzkiej.

Warto w kontekście osiągnięć Soboru Watykańskiego II zwrócić uwagę na zasady hermeneutyki soborowej. Kardynał Walter Kasper w interpretacji dokumentów soborowych, w tym Deklaracji o wolności religijnej, podkreśla element ciągłości oraz odnowy. Według niego twórczy duch odnowy w tworzeniu nierozpoznanych wcześniej ujęć Tradycji i Pisma świętego zawiera recepcję i inkulturację. Tak rozumiane ,aggiornamento” soborowe wskazuje nie tyle na zmianę tego co dawne, ile na odkrycie tego co zawsze było obecne w Objawieniu ${ }^{27}$. Być może właśnie w takim duchu należy patrzeć na Deklarację o wolności religijnej, mając na uwadze, że wcześniej Kościół nie był gotowy na współczesne pojmowanie wolności religijnej.

Podkreślenie natury prawa do wolności religijnej oraz twórczą ciągłość odczytywania Objawienia uzasadnia wychowanie do niej.

\section{WYCHOWANIE DO WOLNOŚCI RELIGIJNEJ}

Teraz należy przejść do kluczowego etapu niniejszej refleksji: wychowania do wolności religijnej. Jeśli mimo pewnych oporów co do idei dokumentu w łonie samego Kościoła, Deklaracja przyniosła pokładane w niej nadzieje ${ }^{28}$, to warto wskazać na jego wytyczne w kwestii wychowania.

\footnotetext{
${ }^{24}$ Marian JAWORSKI, „Wprowadzenie do Deklaracji o wolności religijnej”, w Sobór Watykański II. Konstytucje, dekrety, deklaracje, 405-407.

${ }^{25}$ Janusz MARIAŃSKI, Godność ludzka w kontekście społecznym. Szkice ze społecznego nauczania Kościoła katolickiego (Lublin: Gaudium, 2017), 378-385.

${ }^{26}$ Zob. Józef Tischner, Ksiądz na manowcach (Kraków: Znak, 2007), 121-127; Leszek KoŁaKowsKi, Czy Pan Bóg jest szczęśliwy i inne pytania (Kraków: Znak, 2010), 71-77.

${ }^{27}$ Walter KASPER, Kościól katolicki. Istota, rzeczywistość, posłannictwo, thum. Grzegorz Rawski (Kraków: WAM, 2014), 30-34.

${ }^{28}$ JAWORSKI, „Wprowadzenie do Deklaracji”, 409.
} 
Pierwsze ważne sformułowanie dotyczące wychowania jest następujące: „Prawdy zaś należy szukać w sposób odpowiadający godności osoby ludzkiej i jej społecznej naturze, mianowicie przez wolne dociekania, przez nauczanie i wychowywanie, wymianę myśli i dialog, przez co jedni drugim przedkładają prawdę, którą znaleźli, by pomagać sobie nawzajem w jej zagłębianiu"29. Należy tutaj wskazać na następujące elementy: poszukiwanie prawdy, godność osoby, społeczną naturę człowieka, wolne dociekania, nauczanie, wychowanie, wymianę myśli i dialog. Wcześniej zostało podkreślone uprawnienie człowieka do poszukiwania prawdy i owo poszukiwanie przyczyn ostatecznych wskazuje na religijny wymiar egzystencji człowieka. Poszanowanie godności osoby stanowi zabezpieczenie w tym poszukiwaniu ${ }^{30}$. Społeczna natura egzystencji człowieka uzasadnia prawo do publicznego wyrażania swoich przekonań religijnych. Wolne dociekania stanowią o istocie dochodzenia do wolności religijnej. Wydaje się, że właśnie temu winno służyć wychowanie i nauczanie oparte na wymianie myśli i dialogu. Przy czym zadanie to nie może ograniczać się jedynie do postawy wobec osób inaczej wierzących, ale także do uprawnienia wewnątrz wspólnoty religijnej, co jest także wyraźnym domaganiem się choćby osób katechizowanych ${ }^{31}$. Należy zwrócić uwagę, że istotą wychowania jest rozwój władzy poznawczej i wolitywnej osoby ludzkiej, tak by mogła dążyć do własnej doskonałości moralnej $^{32}$. Wychowanie religijne stanowi zatem ów element wychowania. Rozum niekrępowany w rozwoju poprzez złe mniemania, emocjonalne uzależnienie w sposób wolny winien prowadzić do uznania Boga. Kłopot pozostaje w wyborze religii, tam gdzie posiada ona aspekt kulturowy.

W tym kontekście uprawnienie spoczywa na rodzicach: „Władza państwowa powinna uznać prawo rodziców do dokonywania w pełni wolności wyboru szkół lub innych instytucji kształcenia, a z powodu tej wolności wyboru nie wolno nakładać na nich wprost, ani pośrednio żadnych niesprawiedliwych ciężarów. Ponadto prawo rodziców narusza się wtedy, gdy zmusza się dzieci do uczęszczania na zajęcia szkolne, które nie odpowiadają przekonaniom religijnym rodziców, albo gdy narzuca się jeden model wychowania, który całkowicie wyklucza formację religijną"33. Zatem owo uprawnienie

\footnotetext{
${ }^{29}$ Deklaracja o wolności religijnej, 412, nr 3.

${ }^{30}$ Grzegorz GrzyBeK, Etos życia. Wychowanie do matżeństwa w założeniach etyki rozwoju (Rzeszów: Wydawnictwo UR, 2014), 68.

${ }^{31}$ Grzegorz GRZYBEK, Aktualność idei wychowawczych Józefa Bilczewskiego metropolity lwowskiego w latach 1900-1923 (Bielsko-Biała: Wydawnictwo ATH, 2003), 70-74.

${ }^{32}$ Grzegorz GRzYBEK, Etyka rozwoju a wychowanie (Rzeszów: Wydawnictwo UR, 2010), 73.

${ }^{33}$ Deklaracja o wolności religijnej, 413-414, nr 5.
} 
posiada charakter dwubiegunowy: 1) dotyczący wyboru przeżywania swojej religijności, czy też wyboru światopoglądu oraz 2) wolności od narzucania postaw religijnych i światopoglądowych obcych woli zainteresowanych.

Wolność religijna zawiera wymiar jednostkowy, rodzinny oraz wspólnotowy ${ }^{34}$. W związku z tym ,wspólnoty religijne mają też prawo do nieskrępowanego nauczania swej wiary i publicznego dawania jej świadectwa słowem i na piśmie. W szerzeniu zaś wiary religijnej i we wprowadzeniu zwyczajów należy zawsze powstrzymywać się od wszelkich poczynań, które miałyby posmak przymusu i nalegań nieuczciwych czy mniej stosownych, zwłaszcza w odniesieniu do ludzi prostszych lub potrzebujących. Taki sposób należy uznać za nadużywanie własnego prawa i za naruszanie prawa innych" ${ }^{\text {"35 }}$.

Także uprawnienie wspólnot religijnych $\mathrm{w}$ zakresie wolności religijnej jest dwuaspektowe. Nadaje uprawnienie do określonego wychowania i nauczania oraz zabezpiecza przed narzucaniem określonej wizji religijnej. Warto zauważyć, że szczególność nadużycia w tym aspekcie dotyczy wykorzystania czyjejś niewiedzy, braku wykształconego światopoglądu, czy też bycia w potrzebie egzystencjalnej w odniesieniu do braków środków do życia, czy też kryzysu psychologicznego. To ujęcie prawa do wolności religijnej narzuca również ograniczenie dla danej religii.

Wychowanie do wolności religijnej winno wiązać się także z prawem do szczęścia i należy je odnosić do wychowania do szczęścia. Człowiek w sposób naturalny dąży do szczęścia, stanowi ono podstawowy przedmiot jego starań i wychowanie do szczęścia ${ }^{36}$ wpisuje się w wychowanie do wolności religijnej. „Wychowanie do szczęścia należy rozumieć jako samowychowanie i jego stymulowanie przez innych, opierające się na rozwoju władz poznawczych i wolitywnych. Nadzieja potwierdzająca możliwość spełnienia jest niezbędna do doświadczania radości wynikającej z rozwoju, jak również posiadania przeświadczenia o właściwie obranym kierunku"37.

Wydaje się, że na bazie określenia wychowania do szczęścia można doprecyzować wychowanie do wolności religijnej. Zatem istotą wychowania religijnego jest wychowanie do umiejętności dokonywania wyborów w kategoriach

\footnotetext{
${ }^{34}$ JAWORSKI, Wprowadzenie do Deklaracji, 408-409.

${ }^{35}$ Deklaracja o wolności religijnej, 413, nr 4.

${ }^{36}$ Grzegorz GRZYBEK, „Wychowanie do szczęścia w założeniach «etyki rozwoju»”, w Myśl i praktyka edukacyjna w obliczu zmian cywilizacyjnych, t. 1: Czlowiek $i$ wychowanie $w$ perspektywie wieloetnicznej i wielokulturowej, red. Kazimierz Szmyd, Ewa Barnaś-Baran, Elżbieta Dolata i Anna Śniegulska (Rzeszów: Wydawnictwo UR, 2012), 129-134.

${ }^{37}$ Grzegorz GRzYBEK, Etyka rozwoju a pedagogika opiekuńcza (Rzeszów: Wydawnictwo UR, 2013), 105-106.
} 
religijnych i światopoglądowych mając na uwadze szczęście polegające na rozwoju władz: poznawczej i wolitywnej. Podstawą wychowania do wolności religijnej jest godność osoby ludzkiej i prawo do szczęścia.

Wychowanie do szczęścia, które otwiera na wolność religijną prowadzi też do swoistej „pedagogiki nadziei”, w której potencjalność we właściwy sposób uwidacznia się $\mathrm{w}$ rozwoju ${ }^{38}$. W tym kontekście wychowanie religijne wiąże się procesem osiągania własnej dojrzałości ${ }^{39}$, będącej wyrazem doświadczenia drugiej osoby oraz Stwórcy ${ }^{40}$.

Warto jeszcze przed przejściem do końcowego wniosku odwołać się do problemu otoczenia intelektualno-kulturowego wychowania do wolności religijnej. Globalne zmiany, w tym też w zakresie myślenia etycznego wpływają na ujmowanie religii, zwłaszcza w kontekście sekularyzacji ${ }^{41}$. Do myślenia etycznego ustawiającego stosunek do religii i pojmowania wolności można między innymi zaliczyć: różnorodność i wolność kulturową, świadomość wyboru, $\mathrm{w}$ tym nie tylko $\mathrm{w}$ zakresie religii, ale także płci, równość, również w odniesieniu do równości szans, których sprawy religii nie mogą determinować $^{42}$. Tradycyjne budowanie religijności i doświadczenia religijnego wokół rodziny zostało także wystawione na kryzys wobec rewolucji seksualnej ${ }^{43}$.

Przywoływany już Walter Kasper obok zewnętrznego otoczenia zagrażającego instytucjonalnemu rozwojowi religii zwraca uwagę na kryzys wewnętrzny (spadek powołań kapłańskich, uczestnictwa w sakramentach, rozbicie rodzin, afery wewnątrzkościelne). Biorąc pod uwagę, że epoka powiązania państwa z religią dobiega końca i należy mówić o epoce świeckiej, przestrzega on przed próbą usilnych powrotów do starych praktyk i nieaktualnych form życia religijnego. Wyzwaniem dla myślenia religijnego, osobistego i wspólnotowego są takie elementy jak: samowystarczalny humanizm, wojownicza religijność

${ }^{38}$ Stanisław ChroBAK, „Tożsamość człowieka w prymacie nadziei”, w Personalistyczny wymiar filozofii wychowania, red. Anna Szudra i Katarzyna Uzar (Lublin: Wydawnictwo KUL, 2009), 265-278.

${ }^{39}$ Marian NowAK, Teorie i koncepcje wychowania (Warszawa: Wydawnictwa Akademickie i Profesjonalne, 2008), 435-436.

${ }^{40}$ Stanisław Cz. Michalowski, Pedagogia osoby. Personalistyczne spotkania dialogowe w edukacji (Toruń: Adam Marszałek, 2017), 642-643.

${ }^{41}$ Lukáš ŠvaŇA, Globálna etika (vybrané kapitoly) (Prešov: Filozofická fakulta Prešovskej univerzity, 2019), 27-39.

${ }^{42}$ Por. Marguerite A. PeEters, Nowa etyka w dobie globalizacji, wyzwania dla Kościoła, thum. Grzegorz Grygiel (Warszawa: Wydawnictwo Sióstr Loretanek, 2009), 9-15; Carlo Maria MARTINI, „Krest'anstvo v postmodernom svete”. Nové Horizonty 2, nr 3 (2008): 109-110.

${ }^{43}$ Gabriele KUBY, Globálna sexuálna revolúcia. Strata slobody v mene Slobody (Bratislava: Lúč, 2013), 24-34. 
i równie nietolerancyjny ateizm, sekularyzacja i zepchnięcie religii na margines życia społecznego, czy postmodernizm jako wątpienie we wszystko, zarówno ideały chrześcijańskie, jak również nowożytne oświecenie ${ }^{44}$.

Odpowiedź na wskazane problemy musi się opierać na już przeprowadzonej refleksji. Należy ponadto zauważyć, że intencją wypowiedzi w tym zakresie jest spojrzenie, które ma być propozycją dla jednostki, w jaki sposób może się rozwijać jednostka i wychowywać siebie do wolności religijnej (samowychowanie).

Wniosek zatem może być następujący: wychowanie do wolności religijnej należy także wiązać ze sztuką życia i estetyką egzystencji. Wolny podmiot powinien dokonywać wyborów w tym zakresie w odwołaniu do swojego sposobu bycia, przy świadomości, że jest podstawowym „aktorem życia” odpowiadającym za dokonywane wybory ${ }^{45}$. Wolność religijna, doświadczenie kontaktu ze Stwórcą lub myśl o jego istnieniu stanowi na tyle ważny element etosu życiowego, który nie można pomijać w rozwoju osobowościowym ${ }^{46}$.

\section{BIBLIOGRAFIA}

BAumAn, Zygmunt. Sztuka życia. Tłum. Tomasz Kunz. Kraków: Wydawnictwo Literackie, 2009.

BRONIEwSKI, Witold. Szkice o czlowieku. O doświadczeniu pierwotnym, obdarowaniu i wielkich wyborach życiowych. Toruń: Adam Marszałek, 2006.

CHROBAK, Stanisław. „Tożsamość człowieka w prymacie nadziei”. W Personalistyczny wymiar filozofii wychowania, red. Anna Szudra i Katarzyna Uzar, 265-278. Lublin: Wydawnictwo KUL, 2009.

Compagnoni, Francesco. Prawa człowieka. Geneza, historia i zaangażowanie chrześcijańskie. Tłum. Stefan Bielański. Kraków: WAM 2000.

DAROWSKI, Roman. Filozofia człowieka. Zarys problematyki. Antologia tekstów. Kraków: Ignatianum, WAM, 2008.

Deklaracja o wolności religijnej Dignitatis humanae. W Sobór Watykański II. Konstytucje, dekrety, deklaracje. Tekst polski. Nowe tlumaczenie, red. Maria Przybył, 410-421. Poznań: Pallottinum, 2002.

GRZYBEK, Grzegorz. „Wychowanie do szczęścia w założeniach «etyki rozwoju»”.W Myśl i praktyka edukacyjna $w$ obliczu zmian cywilizacyjnych, t. 1: Człowiek $i$ wychowanie w perspektywie wieloetnicznej $i$ wielokulturowej, red. Kazimierz Szmyd, Ewa Barnaś-Baran, Elżbieta Dolata i Anna Śniegulska, 129-134. Rzeszów: Wydawnictwo UR, 2012.

\footnotetext{
${ }^{44}$ KASPER, Kościót katolicki, 64-72.
}

${ }^{45}$ Por. Zygmunt Bauman, Sztuka życia, thum. Tomasz Kunz (Kraków: Wydawnictwo Literackie, 2009), 93-94; Grzegorz GRZYBEK, Etos i eros. Etyka rozwoju wobec seksualności a samowychowanie (Rzeszów: Wydawnictwo UR, 2020), 197-201.

${ }^{46}$ Grzegorz GRZYBEK, Etyka, rozwój, wychowanie (Bielsko-Biała: Wydawnictwo ATH, 2007), $13-22$. 
GRZYBeK, Grzegorz. Aktualność idei wychowawczych Józefa Bilczewskiego metropolity lwowskiego w latach 1900-1923. Bielsko-Biała: Wydawnictwo ATH, 2003.

GRZYBEK, Grzegorz. Etos i eros. Etyka rozwoju wobec seksualności a samowychowanie. Rzeszów: Wydawnictwo UR, 2020.

GRzYBEK, Grzegorz. Etos życia. Wychowanie do małżeństwa w założeniach etyki rozwoju. Rzeszów: Wydawnictwo UR, 2014.

GRZYBEK, Grzegorz. Etyka rozwoju a pedagogika opiekuńcza. Rzeszów: Wydawnictwo UR, 2013.

GRZYBEK, Grzegorz. Etyka rozwoju a wychowanie. Rzeszów: Wydawnictwo UR, 2010.

GRZYBEK, Grzegorz. Etyka, rozwój, wychowanie. Bielsko-Biała: Wydawnictwo ATH, 2007.

GRZYBEK, Grzegorz. „Uprawnienie do wolności - interpretacja etyczna”. W O prawach czlowieka nieco inaczej, red. Ryszard Moń i Andrzej Kobyliński, 169-175. Warszawa: Wydawnictwo UKSW, 2011.

JAN XXIII. Pacem in terris. Encyklika o pokoju między wszystkimi narodami opartym na prawdzie, mitości i wolności. Wrocław: TUM, 1997.

JAWORSKI, Marian. „Wprowadzenie do Deklaracji o wolności religijnej”. W Sobór Watykański II. Konstytucje, dekrety, deklaracje. Tekst polski. Nowe tlumaczenie, red. Maria Przybył, 405-409. Poznań: Pallottinum, 2002.

KASPER, Walter. Kościół katolicki. Istota, rzeczywistość, posłannictwo. Tłum. Grzegorz Rawski. Kraków: WAM, 2014.

Katechizm Kościoła Katolickiego. Poznań: Pallottinum, 1994.

KŁoczowski, Jan A. „Poznanie religijne. Próba charakterystyki”. Logos i Ethos 2, nr 1 (1992): 13-21.

KoŁaKowsKi, Leszek. Czy Pan Bóg jest szczęśliwy i inne pytania. Kraków: Znak, 2010.

KoŁAKOWSKI, Leszek. „Symbole religijne i kultura humanistyczna”. W: Leszek KoŁAKOwsKi, Kultura i fetysze. Eseje, 221-239. Warszawa: PWN, 2009.

KowAlCzyK, Stanisław. Filozofia kultury. Próba personalistycznego ujęcia problematyki. Lublin: Wydawnictwo KUL, 2005.

KowAlCZYK, Stanisław. Zarys filozofii człowieka. Sandomierz: Wydawnictwo Diecezjalne, 2002.

Kuby, Gabriele. Globálna sexuálna revolúcia. Strata slobody v mene Slobody. Bratislava: Lúč, 2013.

MAREK, Zbigniew. Religia, pomoc czy zagrożenie dla edukacji? Kraków: WAM, 2014.

MARIAŃSKI, Janusz. Godność ludzka w kontekście społecznym. Szkice ze społecznego nauczania Kościoła katolickiego. Lublin: Gaudium, 2017.

MARIAŃSKI, Janusz. „Religia i moralność w społeczeństwie polskim - ciągłość i zmiana”. $\mathrm{W}$ Wartości $i$ więzi moralne $w$ zmieniającym się społeczeństwie, red. Janusz Mariański i Leon Smyczek, 269-300. Kraków: WAM, 2008.

Martini, Carlo Maria. „Krest'anstvo v postmodernom svete”. Nové Horizonty 2, nr 3 (2008): 109-110.

MichaŁowski, Stanisław Cz. Pedagogia osoby. Personalistyczne spotkania dialogowe w edukacji. Torun: Adam Marszałek, 2017.

NowAK, Ewa, i Karolina CERN. Ethos w życiu publicznym. Warszawa: PWN, 2008. 
NowAK, Marian. Teorie i koncepcje wychowania. Warszawa: Wydawnictwa Akademickie i Profesjonalne, 2008.

PeEters, Marguerite A. Nowa etyka $w$ dobie globalizacji, wyzwania dla Kościoła. Tłum. Grzegorz Grygiel. Warszawa: Wydawnictwo Sióstr Loretanek, 2009.

PIECHOWIAK, Marek. Filozofia praw człowieka. Prawa człowieka w świetle ich międzynarodowej ochrony. Lublin: Towarzystwo Naukowe KUL, 1999.

Powszechna Deklaracja Praw Człowieka. W: Roman DAROwSKI, Filozofia człowieka. Zarys problematyki. Antologia tekstów, 243-248. Kraków: Ignatianum, WAM, 2008.

SKOROwSKi, Henryk. Problematyka praw czlowieka. Warszawa: Wydawnictwo UKSW, 1999.

ŠvaŇA, Lukáš. Globálna etika (vybrané kapitoly). Prešov: Filozofická fakulta Prešovskej univerzity, 2019.

TISCHNER, Józef. Ksiądz na manowcach. Kraków: Znak, 2007.

TischNER, Józef. W krainie schorowanej wyobraźni. Kraków: Znak, 2013.

Valverde, Carlos A. Antropologia filozoficzna. Tłum. Grzegorz Ostrowski. Poznań: Pallottinum, 1998.

WoJTyŁA, Karol. Rozważania o istocie człowieka. Kraków: WAM, 2003.

ZDYBICKA, Zofia J. „Człowiek i religia”. W: Mieczysław A. KRĄPIEC, Ja-czlowiek: zarys antropologii filozoficznej, 355-400. Lublin: Wydawnictwo KUL, 2005.

\section{KULTUROWY WYMIAR WOLNOŚCI RELIGIJNEJ A WYCHOWANIE. WSPÓŁCZESNE ZNACZENIE DEKLARACJI O WOLNOŚCI RELIGIJNEJ}

$$
\text { Streszczenie }
$$

Celem artykułu było z jednej strony podkreślenie kulturowych przemian w zakresie religijności, których wyrazem jest Deklaracja o wolności religijnej Soboru Watykańskiego II, zaś z drugiej wskazanie na wychowanie do wolności religijnej, które winno wiązać się z wychowaniem do szczęścia oraz ze sztuką życia. Wychowanie do szczęścia oraz umiejętność sztuki życia opierają się na wolności wyboru, a także godności osoby ludzkiej.

Słowa kluczowe: wolność religijna; wychowanie; szczęście; godność; deklaracja.

\section{THE CULTURAL DIMENSION OF RELIGIOUS FREEDOM AND EDUCATION: THE SIGNIFICANCE OF THE DECLARATION ON RELIGIOUS FREEDOM TODAY}

\section{S u m m a ry}

The aim of the article is to emphasize the cultural changes in religiousness, addressed by the Declaration on Religious Freedom of the Second Vatican Council, and to indicate education for religious freedom, which should involve education for happiness and the art of living. Education for happiness and human life skills rely on the freedom of choice and the dignity of the human being.

Keywords: religious freedom; education; happiness; dignity; declaration. 